\title{
The Effectiveness of an Entrepreneurship Learning Model in Growing Competence and Entrepreneurial Intention of Vocational High School Students in East Java Indonesia
}

\author{
Agus Prianto \\ Senior lecturer of Economic Education Department \\ STKIP PGRI Jombang East Java \\ Indonesia \\ Siti Zoebaida \\ Productive Accounting Teacher at SMKN 2 Madiun East Java \\ Indonesia \\ Ahmad Sudarto \\ Entrepreneurship Teacher at SMK PGRI 1 Giri Banyuwangi East Java \\ Indonesia \\ Retno Sri Hartati \\ Productive Accounting Teacher at SMKN 1 Jombang East Java \\ Indonesia
}

\begin{abstract}
The high unemployment rate of vocational high school graduates, as released by Central Statistic Bureau (BPS) in 2017, raises the notion that the entrepreneurship culture is still not entrenched. This raises the question, whether the entrepreneurial learning activities have been effective for improving the entrepreneurship competence and entrepreneurial intention of the graduates? This research is applied to the $12^{\text {th }}$ graders in Surabaya, Malang, Jombang, Madiun and Banyuwangi. In this study, entrepreneurship learning is grouped into 3 categories, namely: entrepreneurship theoretical learning, entrepreneurship theoretical learning combined by business practices, and entrepreneurship theoretical learning combined by student involvement in the business activities. To obtain the data, students were asked to conduct self assessment of entrepreneurial competence perceived based on 3 learning models they received. At the same time, students are asked to express their entrepreneurial intention perceptions. Descriptive and statistical analysis is used to analyze the data. This study revealed that entrepreneurial learning activities combining theoretical studies and involving students to business activities is the most effective learning model to improve entrepreneurship competence of students, especially for skill dimension and entrepreneurial attitude. The entrepreneurial learning activities combining theoretical studies and involving students to business activities is also effective to grow students entrepreneurial intention, especially the encouragement to entrepreneurship, immediately creating business activity after graduation, the effort to entrepreneurship, and set entrepreneurship profession as the first choice after graduation. This study recommends to schools that entrepreneurship learning activities should emphasize more on the theoretical study combined with the student involvement in business activities. This can be done by optimizing the business centre function, and strengthening the cooperation with the business institution.
\end{abstract}

Keywords: entrepreneurship learning, entrepreneurial competence, entrepreneurial intention

\section{Introduction}

There are two main problems faced by the graduates of educational institutions in the face of very tough competition era as today. First, it relates to the readiness of graduates to compete in the job market (Prianto, et.al., 2017). Second, it relates to the lack of graduates' enthusiasm for entrepreneurship (Prianto, 2017). These two problems faced by graduates makes an educated unemployment still high at the moment. The study conducted by Prianto (2015) revealed an interdependence relation between the graduates readiness to compete with high and low enthusiasm for entrepreneurship. 
Prianto (2015) explains that graduates with entrepreneurship spirit are proved to be more ready to face the competition. Until now, the education and training in the field of entrepreneurship is still considered to be an important role in strengthening the entrepreneurship spirit of learners. Various literatures explain the important role of education and training in growing the entrepreneurship encouragement. Various literatures explain that the ownership of entrepreneurship spirit is not only due to innate or born factors while it automatically attaches to a person. Entrepreneurship spirit can be formed and prepared or made through education and training activities, so that a person can become a formidable entrepreneur. Therefore, to the date various formal educational institutions teach entrepreneurship education designed to equip learners the entrepreneurship. Thus, it can later become a successful entrepreneur.

Although entrepreneurship education plays an important role in preparing for new born of entrepreneurs, the study conducted by Lynes, Wismer, and rachuk (2011) found that entrepreneurship education taught in the classical format in the formal education system is considered not to have a strong influence in preparing for new born of female entrepreneurs. Lynes, Wismer, and Andrachuk (2011) found that entrepreneurship education in the informal format acquired by young people through family and colleagues plays an important role in strengthening entrepreneurial spirit. Entrepreneurship education is designed to equip experiences and practices proves to inspire young people to be entrepreneurs.

Drucker (1985) explains that entrepreneurship as a knowledge that can be learned by everyone. some previous studies have revealed that the success of entrepreneurship is influenced by entrepreneurship education (Weaver, et.al, 2006; Menzies \& Paradi, 2002). Some studies have revealed that entrepreneurship education can foster the passion of learners to become an entrepreneur (Kumar et al, 2013; Izedomi \& Okafor, 2010). Another study has revealed that entrepreneurship education packaged in an entrepreneurship education and training format can strengthen communication skills and language skills (Lynes, Wismer, and Andrachuk (2011) .Thus, Coduras, et.al. (2008) explains that it is important to integrate education and training into formal education activities at various levels.

Vocational High School (SMK) is one of the secondary education level that aims to prepare learners in order to have readiness to work and to do entrepreneurship. Haryono (1995) explains that vocational education basically has three main functions, namely: (1) talent development function, vocational education provides educational services to learners to develop their talents and interests in order to be ready to work in their respective fields, (2) the basic skill education directed to the work world, vocational education should teach basic skills relevant to the demands of the job market, (3) coaching functions, vocational education provides training to learners to develop skills in accordance with their talents and interests in order to become an independent entrepreneur.

Strengthening entrepreneurial spirit is also to be the concern of the Directorate of Vocational Education. They strengthen the entrepreneurial learning oriented to the formation of entrepreneurial, innovative, and creative through the Festival of Innovation and Entrepreneurship for Vocational Students (FIKSI)

(portal.ditpsmk.net/.../bandung-siap -friends-fiction-2016).

To date, Vocational High School is still facing a tough challenge to show its role and function in creating graduates with their readiness to work and do entrepreneurship. The Central Statistic Bureau reported that there has been an increase in the unemployment rate by 2017, and judging from the educational background, the vocational high schools (SMK) graduated the highest unemployment rate, it is $11.41 \%$ compared to other education levels, ( https: // economy. kompas.com/read/2017/11/06/153940126/agustus-2017-the number ofemployees-weight-to-704-million- people ). The high unemployment rate of SMK graduates is like the contrary to the government design. From the beginning, the design was intended to prepare graduates with high readiness to enter the job market and to do entrepreneurship. In connection with the strengthening of entrepreneurship spirit, this raises the question: "Is entrepreneurship education in vocational school really effective to foster interest for entrepreneurship among learners?" This study intends to examine the extent to which the effectiveness of entrepreneurship education activities in growing interest in entrepreneurship of vocational school students in East Java.

\section{Entrepreneurship Education in SMK}

Having a lot of data expressing the lack of entrepreneurial culture among graduates of educational institutions, this then raises the question from many experts: "Can entrepreneurship be taught?" (Lackeus, 2013). 
Various studies have revealed that entrepreneurship can be taught to learners (Lackeus, 2013; Kuratko, 2005; Gorman, et.al., 1997). But experts also agree that to deliver the learners become an entrepreneur, then it is not enough done through classical entrepreneurship education in the classroom, but it must provide opportunities for learners to gain experience through learning by doing and the direct observation of entrepreneurial activity. To that end, entrepreneurship education should provide more opportunities for learners to engage on the job learning activities and learn through the experience of operating business activities (Lackeus, 2013). In other words, entrepreneurship can be learned informally and can be taught through formal education (Lange, et.al., 2011).

Assuming as experts have found that entrepreneurship education can be taught, the government requires vocational high schools to teach entrepreneurship. To provide an entrepreneurial experience directly to learners, the vocational high school then obliges the learner to join an entrepreneurial internship program. The government, through the Directorate of Vocational Guidance, requires schools to have a business center as a place for students to practice entrepreneurship.

In countries where entrepreneurial culture is already stronger like in the Netherlands, entrepreneurship education is designed to prepare learners to be entrepreneurs in the future. To achieve the goal, there are some steps and strategies taken, namely: (1) to train students in order to have an independent attitude, (2) to equip learners with the various skills and steps that must be taken to be a successful entrepreneur, (3) to popularize the field of entrepreneurship as a noble profession, (4) to strengthen the entrepreneurial culture in the schools(Ministry of Economic Affairs, 2000).

Strengthening entrepreneurship spirit for students of SMK is emphasized by the government through Law Number 17 of the Year 2007 on the National Long Term Development Plan of the Year 2005-2025. The President's speech at the National Summit 2010 mandates the need to promote entrepreneurial spirit and educational methodology directed at developing entrepreneurial spirit (Mulyani, 2010). Strengthening entrepreneurship spirit for students of SMK is done through various efforts, including: (1) inculcate entrepreneurship education into all subjects, teaching materials, extracurricular, and self-development, (2) develop educational curriculum. The content of curriculum provides entrepreneurship education that can improve understanding about entrepreneurship, fostering character, and entrepreneurship skills, (3) foster entrepreneurial culture in the school environment through school culture (Mulyani, 2010). Referring to the Center for Curriculum and Agency for Research and Development, Ministry of Education and Culture, implementing entrepreneurship education in SMK can be described as follows (Mulyani, 2010):

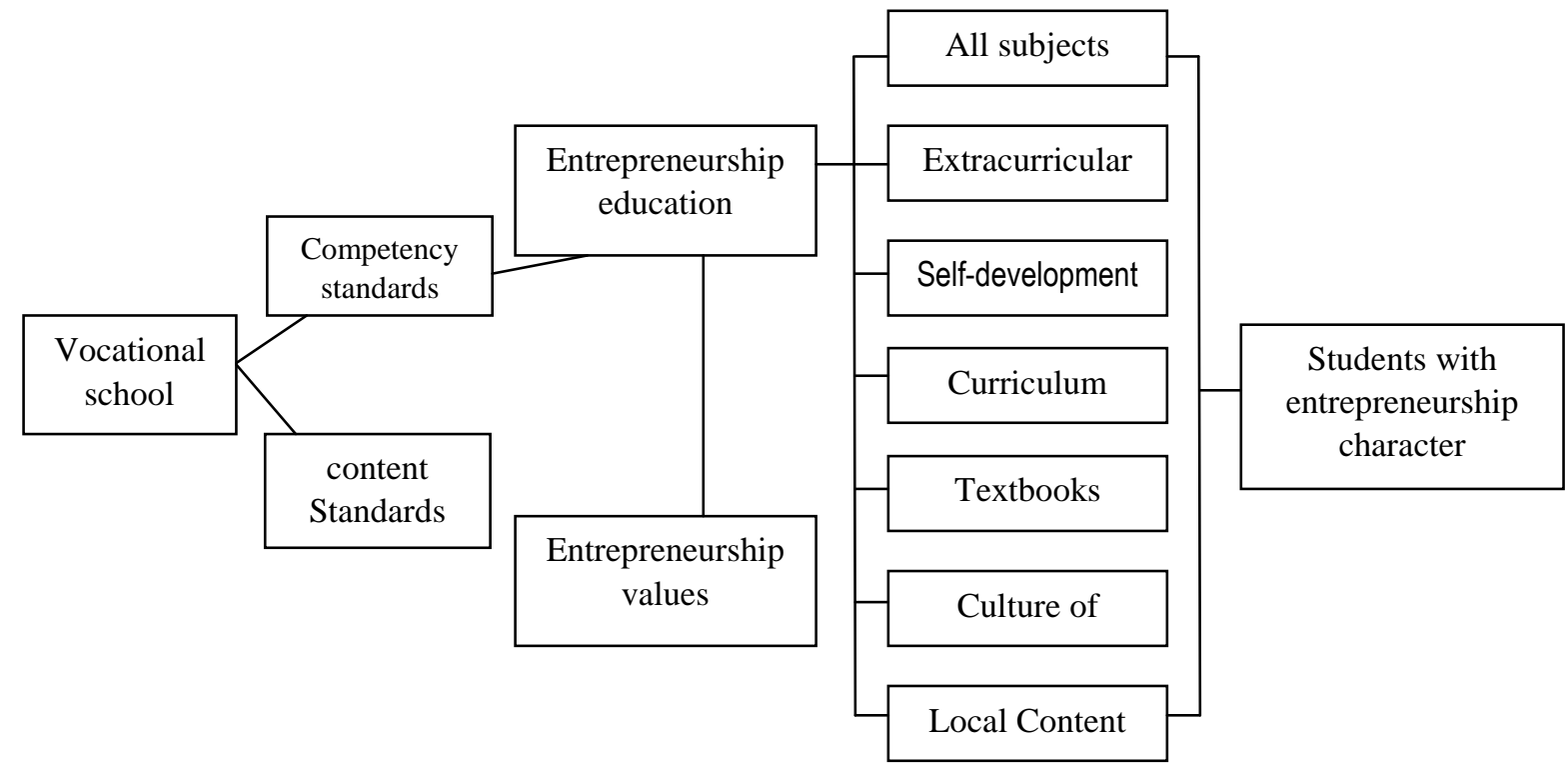

Figure 1: Entrepreneurship Education Model in Vocational school Version of Center for Curriculum and Agency for Research and Development, Ministry of Education and Culture

The final goal of entrepreneurship education is to develop entrepreneurial competence of learners (Lackeus, 2013). Entrepreneurship education in schools is generally to equip learners to be able to identify business opportunities, develop business activities, become self-employed, and learn to become an entrepreneur. 
In a broader definition, entrepreneurship education is intended for self-development, creativity, confidence, initiative (Fayolle \& Gailly, 2008), and the strengthening of entrepreneurial culture demonstrated by various habits such as keep studying, having a sense of wonder and encouraging to try something new, creativity, initiative, teamwork, and personal responsibility (Lackeus, 2013).

Some experts describe 3 approaches to entrepreneurship teaching in schools: first, entrepreneurship learning with emphasizing theoretical studies; second, employment-oriented learning, this learning encourages learners to practice become an entrepreneur, fosters students' interest in becoming entrepreneur with knowledge and skills in the field of entrepreneurship; third, learning through entrepreneurial activities, this learning invites learners to engage directly in business activities (O'Connor, 2013; Heinonen \& Hytti, 2010; Kyro, 2008).

The study conducted by Usman and Raharjo (2012) describes a new model of entrepreneurship education in vocational schools. The model is expected to strengthen the entrepreneurship spirit of learners more effectively. The model developed by Usman and Raharjo (2012) refers to the opinion of Noah (2010), he explains that strengthening the character including entrepreneurial character will involve four pillars, namely: (1) teaching and learning activities in the classroom, (2) daily activities in form of cultural strengthening at the level of formal and non formal education, (3) strengthening of co-curricular activities, outside classroom activities directly relates to the subject; and extracurricular activities, the development activities of the learner 's personality that is not directly related to the subject, and (4) the daily activities of learners at home and in the society.

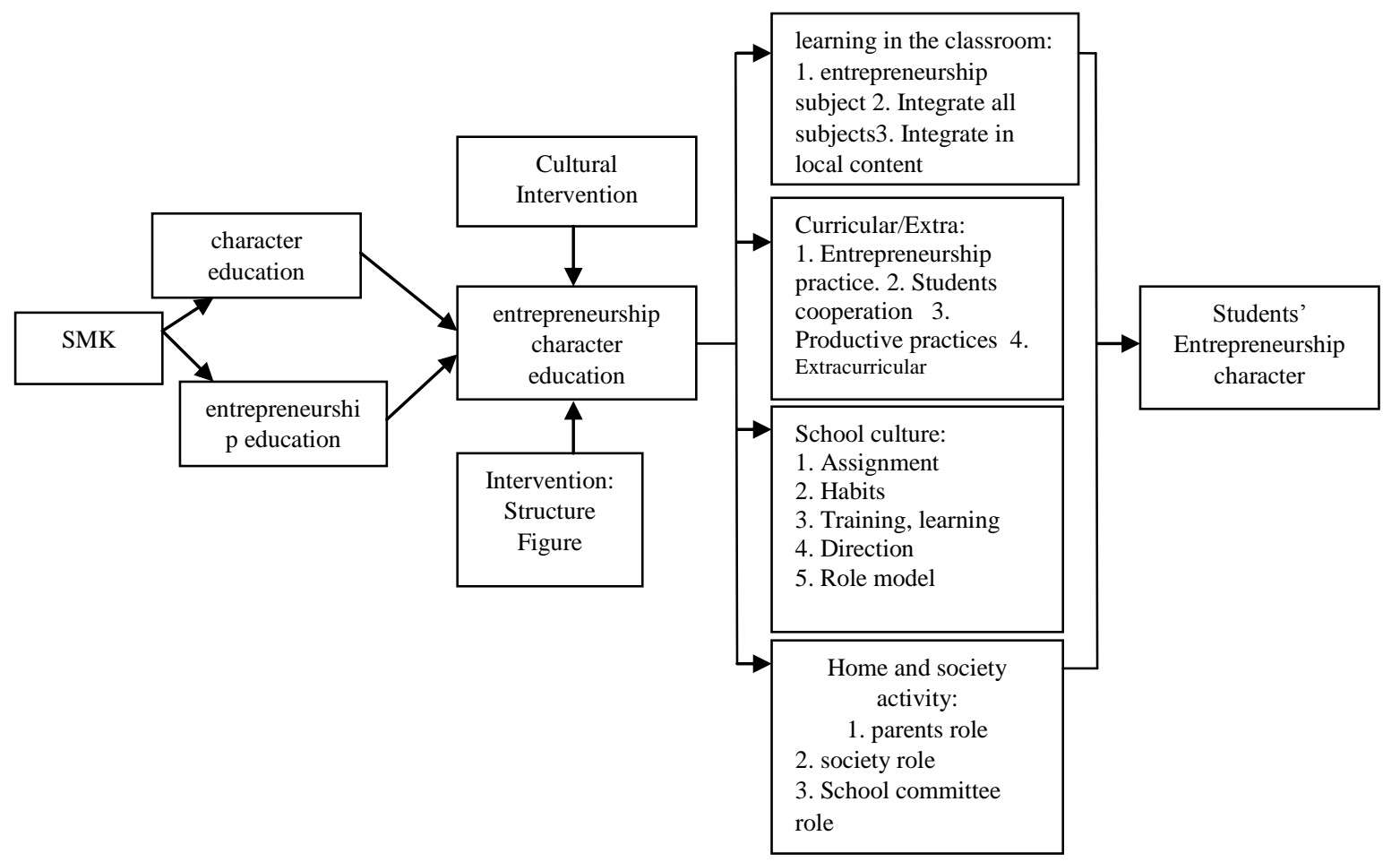

Figure 2: The Model of Entrepreneurship Education in SMK According to Usman and Raharjo (2012)

By paying attention to entrepreneurship education model as developed by Usman and Raharjo (2012), it was explained that the approach of learning about entrepreneurship is theoretically done in the class. A learning approach directed to take learners to be entrepreneur is implemented through curricular and extracurricular activities, such as activities of entrepreneurship practices, productive business practices, and students cooperation. The learning approach through entrepreneurship activities is carried out by involving learners in entrepreneurial activities developed by parents, societies, and business center activities owned by the school.

Growing interest in entrepreneurship among learners, it can not surely be done only through entrepreneurship education in schools. A study conducted by Prianto (2012) proves that the family environment, social environment, and entrepreneurship education in schools are sequentially the three main factors driving the entrepreneurial orientation. In other words the family and social environment are two main factors that effectively foster entrepreneurship intention. 
It means the growth of entrepreneurship intention among learners need support the involvement of the family and the social environment. In this context, a strong entrepreneurial culture must be applied in the family and society environment. Various questions are often raised by entrepreneurial researchers, such as: Why do people want to be entrepreneurs, while others with equal talents and competencies are not interested in becoming entrepreneurs? Why is a person able to see business opportunities, while others who have the same experience and information cannot afford to see a business opportunity? Why is a person able to turn ideas into a business activity, while others just stop at the level of ideas and thoughts? (Mitchell, et.al., 2007). These questions reinforce the assumption that strengthening entrepreneurship interests is not enough to be done only through the learning process in school, especially if the learning process is more theoretical.

Entrepreneurial reinforcement, as Prianto (2012) found, it should involve more education role in family environment and social environment. The society should be able to become stimulator which can encourage someone to be interested in becoming an entrepreneur. The study conducted by Matthews and Moser (1995) proves that the entrepreneurial activities of parents are used as the next generation model for entrepreneurship. Entrepreneurial activities run by families and parents are the earliest entrepreneurial socialization of the next generation. The entrepreneurial socialization taking place at home will further influence the next generation in choosing a career as an entrepreneur.

The involvement of various social structures in society in the cultivation of entrepreneurial culture is an important factor that contributes to the success of entrepreneurial activities. Various customs and activities run by citizens will influence the choice of activities of other citizens. It means that if in the society entrepreneurship activities become the center activities of the citizens, then this has the potential to encourage other citizens to have similar activities (Davidson, 1995; Goel, et.al, 2007). In this study, the learning patterns of entrepreneurship for learners are grouped into three categories: (1) the explanation of theoretical entrepreneurship materials in the classroom, (2) entrepreneurship practice, and (3) internships or directly involved in business activities.

\section{Entrepreneurship Competencies}

Competence is a term widely used in the field of human resource development, and is commonly used to measure a person's performance. A person possessing a competency is characterized by possession of knowledge, passion and desire, positive attitude, and proficiency in the work field. Competencies are related to performance, in accordance with work standards, and can be further improved through education, training and development activities. In short, competence is related to the various behaviors of a person who support their success in work (Moore, et.al., 2002).

Referring to the criteria as proposed by Johannisson (1991), someone who has the competence of entrepreneurship if they have criterias as follows: (1) know-what, knowledge of entrepreneurship, (2) know-when, entrepreneurship insight, (3) know-who, possession of social skills, (4) know-how, possession of various entrepreneurship skills, (5) know-why, have attitude, values, and motivation related to entrepreneurial activity.

This study identifies entrepreneurial competencies, referring to Lackeus (2013) and other experts that consisting three dimensions, namely: (1) the dimensions of knowledge (K), (Kraiger, et.al., 1993), (2) skills (S), (Fisher et al, 2008), and ( 3) Attitude (A), (Fisher, et.al., 2008; Krueger, 2007; Murnieks, 2007; Markman, et.al., 2005). These dimensions include 15 indicators. The dimension of knowledge $(\mathrm{K})$ are: (K1) possessing entrepreneurship knowledge, (K2) mental as an entrepreneur, and (K3) entrepreneurial insight. The dimensions of skills (S) are: (S4) marketing skills, (S5) opportunity skills, (S6) resource skills, (S7) interpersonal skills, (S8) learning skills, and (S9) strategic skills. While the attitude dimension (A) are: (A10) entrepreneurial passion, (A11) confidence and self efficacy, (A12) pro-activeness, (A13) dare to face uncertain situation, (A14) innovativeness, and (A15) perseverance.

\section{Entrepreneurial Intention}

Effective entrepreneurship learning will be characterized by the growth of preference, passion, interest, and encouragement from within the learner to conduct business activities. Entrepreneurial culture should be strengthened by examining the factors that can encourage entrepreneurship interest (Krueger, Reilly, \& Carsrud, 2000). Entrepreneurial intention is related to the psychological dimension. Krueger et al. (2000) states that interest is a major factor of various planned behaviors. Thus if a person is not currently engaged in entrepreneurial activity, and he is interested to be involved in it; then the entrepreneurial activity for that person belongs to the category of planned behavior. 
Ajzen (1991) was the first reviewer of planned behavior (Theory of Planned Behavior, TPB). Through TPB, we get an explanation of how to change one's behavior. The main concern of TPB is interest, it can be a passion and hope that can encourage a person to behave a certain thing. Thus if a person has a strong interest in certain things, then it will give a strong encouragement to someone to engage in the field. So, the higher interest in an entrepreneurship will be the higher in entrepreneurial intention.

Ajzen (1991) describes three important factors that will turn interest into actual behavior. First, one's beliefs and attitudes will encourage them to behave in a certain way. Krueger et al. (2000) gives an example of a learner who has a positive attitude towards entrepreneurship because both parents work as entrepreneur. Second, social factors in the context of subjective norms developed by individuals. This factor refers to the pressures that individuals must face from their social environment to behave or not. For example, if a person has negative experience and insight about entrepreneurship then he will prohibit his family from engaging in entrepreneurial activities. Conversely, if a person has a positive view of entrepreneurship then he will provide support to engage in entrepreneurial activities. Third, behavior control factors. One will realize that their behavior on entrepreneurship is not only driven by interest, but also influenced by how a person assesses himself about the obstacles that must be faced to engage in entrepreneurial activity.

The study conducted by Steward, et.al (1998) reveals that one's encouragement to entrepreneurship is influenced by internal factors, external factors, and contextual factors. Nishanta (2008), Krueger et al., (2000), and Bird \& Jelinek (1988) describe some of the internal factors that have been shown to influence the entrepreneurial encouragement. the factors are individual skills, individual character, entrepreneurial perception, independence, socioeconomic factors and demographics including age, gender, experience, educational background, and family background. While external and contextual factors affecting entrepreneurship interest are government policy support, market opportunity, business environment support, social award, business experience, and educational activities and training in entrepreneurship (Gorman, et.al., 1997; Rasheed, 2000; Gerry, et.al. , 2008; Gurbuz \& Aykol, 2008). Thus, in this study, the interest in entrepreneurship will be seen from the appearance of various attributes in the learners, including: (I1) ideals, (I2) interest, (I3) effort, (I4) self-preparation, (I5) desire, (I6) hope, (I7) encouragement for entrepreneurship, (I8) immediately actualize any business after graduation, and (I9) set the entrepreneurial profession as the first choice.

\section{Research Method}

The research is conducted to students of $12^{\text {th }}$ grade of vocational high school in 5 selected cities in East Java: Surabaya, Malang, Jombang, Madiun, and Banyuwangi. Deciding the respondents from students of $12^{\text {th }}$ grade of vocational high school is based on the consideration that they have received entrepreneurship subjects both in theory and practice. They are also assumed to have been involved in internship program. The total sample of the study are 150 students, each city is taken as 30 students. Sampling technique is accidental sampling technique, by considering the large population and widely spread the location of students' residence.

The data collection is done by self assessment technique which gives opportunity to the student to evaluate themselves related to the level of mastery of 15 entrepreneurial competencies. Students are given the opportunity to score their mastering perceived competency with a score range 1 to 10 . Meanwhile, to measure entrepreneurship interest, the data collection is done with a questionnaire of different semantic technique model, which provides an opportunity to students to express the perception of entrepreneur interest, with a score range 1 to 10. The degree of mastery of entrepreneurial competencies and entrepreneurship interests is measured in accordance with the entrepreneurial learning models that they have studied through the three categories of learning activities: (1) theoretical entrepreneurial learning in the classroom, (2) entrepreneurship practice, and (3) internships or directly involved in business activities. Data Analysis is done by describing the mastery of entrepreneurship competence and entrepreneurship interest of the learners based on the learning models that they have studied. The effectiveness analysis of the application of entrepreneurship learning model to the level of entrepreneurship competence and entrepreneurship intention is done by univariate test .

\section{Results and Discussion}

The following is the description of students' self-assessment results on perceived entrepreneurial competence and entrepreneurial interest after they studied entrepreneurial learning activities with three learning models: (1) theoretical entrepreneurship learning in the classroom, (2) entrepreneurship practice, and (3) internships or directly involved in business activities. 
The result of self-assessment about entrepreneurial competence is based on three models of entrepreneurial learning they received, as shown in Figure 3. Based on the data in Figure 3, it can be seen that theoretical entrepreneurship learning in the classroom is not enough to develop entrepreneurial competence of learners. The results of self-assessment revealed that the average of entrepreneurial competence mastery they perceived after studying entrepreneurship theory is at the average score of 4.08 (40.8\%). Entrepreneurship competence of learners after studying entrepreneurship through theoretical activities and followed by business practice activity is at the average score of $6.56(60.56 \%)$. Entrepreneurship competence of learners after studying entrepreneurship through theory activities and directly involved in business activities is at the average score of 7.66 $(70.66 \%)$. These show that the enhancement of entrepreneurship competencies of vocational school students will be more effective if the students immediately follow business practices after studying the entrepreneurship theory and directly involve in business activities.

Although there is not significantly change, students gain entrepreneurial knowledge (K1) through business practices and directly involved in business activities. But this study revealed that the entrepreneurial mentality (K2) and entrepreneurship insight (K3) of learners change significantly after they follow the business practices and involve in business activities. This proves that to strengthen the passion and insight of entrepreneurship of the younger generation must be done by involving them into various business activities, and conditioning the social environment with various business activities.

The entrepreneurship learning combining the theory, business practice and directly involved in the business activities has been proven that it improves students' skills, such as: (S4) marketing skills, (S5) Opportunity skills, (S6) resource skills, (S7) interpersonal skills, (S8) learning skills, and (S9) Strategic skills (see figure 3). This proves that business practices and involving learners in business activities are an effective learning approach to improve the skills of entrepreneurs.

Entrepreneurship learning, combining the theory, business practice and directly involved in the business activities, is proved to be effective in strengthening entrepreneurship attitude of learners, especially for the attitude dimension: (A10) entrepreneurial passion, (A11) confidence and self efficacy, and (A14) innovativeness, (see figure 3). This proves that business practices and involving learners in business activities are an effective learning approach to strengthen entrepreneurial attitudes, foster self-confidence, and develop innovation skills.

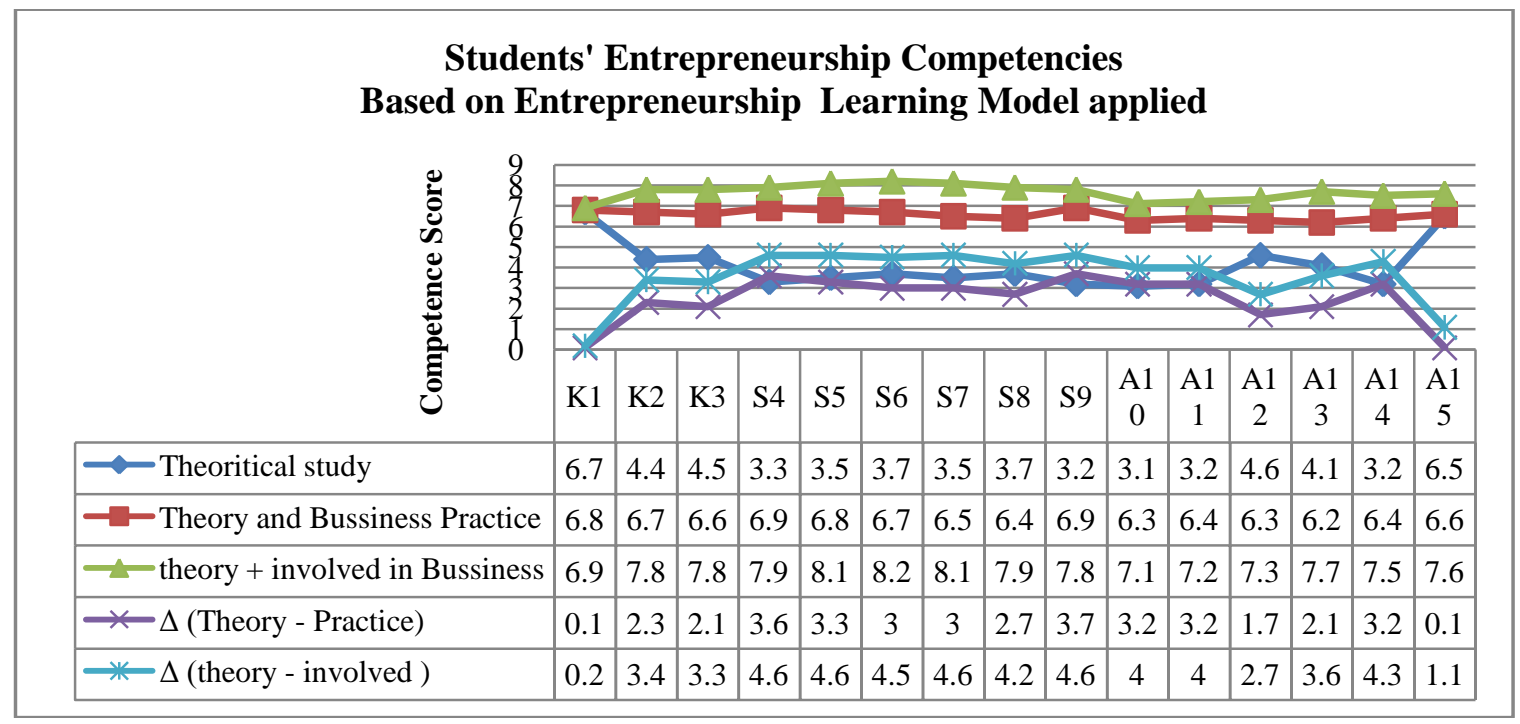

Figure 3: Students' Entrepreneurship Competence Based on Entrepreneurship Learning Model Applied

Students' perceptions of entrepreneurship intention are based on the three Entrepreneurship learning models they received, as shown in Figure 4. Students stated that the average of entrepreneurship interest they perceived after studying entrepreneurship was at the average score of 4.04 (40.4\%). Students' entrepreneurship interest after attending entrepreneurship learning through theory activities and followed by business practices is at the average score of $7.24(70.24 \%)$. Students' entrepreneurship interest after attending entrepreneurship learning through theory activities and directly involved in business activities is at the average score of $8.22(80.22 \mathrm{~s} \%)$. 


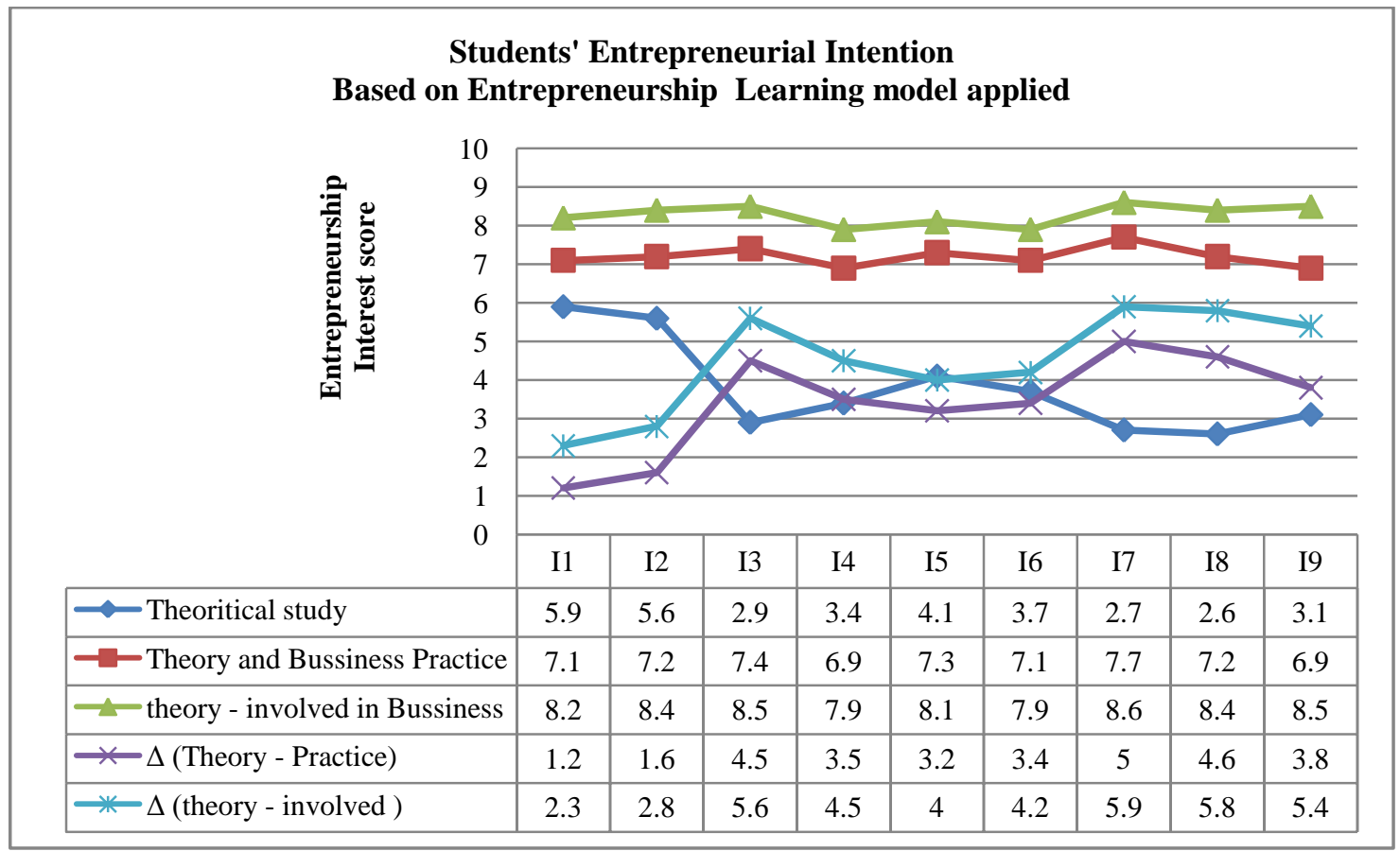

Figure 4: Students' Entrepreneurship Intention Based on Entrepreneurship Learning Model Applied

Entrepreneurship learning combining the theory, business practice and directly involved in the business activities has been proven that it increases students' entrepreneurship interest, especially for the dimensions of: (1) encourage to entrepreneurship (I7), (2) immediately manifests after graduation (I8), 3) entrepreneurship effort (I3), (4) set the entrepreneurial profession as the primary choice (I9), (5) interested in becoming entrepreneur (I2), (6) hope for entrepreneurship (I6), and (7) desire for entrepreneurship (I5). This proves that Entrepreneurship learning combining the theory, business practice and directly involved in the business activities is more effective in growing entrepreneurial interest; especially for the dimensions of encouragement to entrepreneurship, immediately manifests after graduation, and the effort of learners to entrepreneurship.

Table: The Differences of Learning Method Effect to Students' Competence and Interest in Entrepreneurship

\begin{tabular}{|c|c|c|c|c|c|}
\hline \multirow{2}{*}{ Variabel } & \multicolumn{2}{|c|}{ Learning Method } & \multirow{2}{*}{$\begin{array}{c}\text { Different } \\
\text { mean }(A-B)\end{array}$} & \multirow{2}{*}{ S.E. } & \multirow{2}{*}{ Sig. } \\
\hline & $\mathbf{A}$ & B & & & \\
\hline \multirow{3}{*}{$\begin{array}{l}\text { Entrepreneurship } \\
\text { Competence }\end{array}$} & \multirow{2}{*}{$\begin{array}{l}\text { Involved in } \\
\text { business } \\
\text { activities }\end{array}$} & Theoretical review & $3.7533 *$ & .08535 & .000 \\
\hline & & Business Practice & $1.3400 *$ & .08535 & .000 \\
\hline & $\begin{array}{l}\text { Business } \\
\text { Practice }\end{array}$ & Theoretical review & $2.4133 *$ & .08535 & .000 \\
\hline \multirow{3}{*}{$\begin{array}{l}\text { Entrepreneurial } \\
\text { Intention }\end{array}$} & \multirow{2}{*}{$\begin{array}{l}\text { Involved in } \\
\text { business } \\
\text { activities }\end{array}$} & Theoretical review & $3.8477^{*}$ & .09184 & .000 \\
\hline & & Business Practice & $1.2870 *$ & .09184 & .000 \\
\hline & $\begin{array}{l}\text { Business } \\
\text { Practice }\end{array}$ & Theoretical review & $2.5607 *$ & .09184 & .000 \\
\hline
\end{tabular}

*) Significant Different Mean at $\alpha=.05$

This study proved that the most effective learning approach to strengthen the competence of entrepreneurship and Entrepreneurial intention of students in sequence are as follows: (1) Learning entrepreneurship theoretically and followed by involving students directly on business activities, (2) Learning entrepreneurship theoretically and followed with business practices, and (3) Learning entrepreneurship theoretically in a classical format. The results shown that to strengthen the competence of entrepreneurship and Entrepreneurial intention of learners, the effective entrepreneurship learning model in sequence are as follows: 
(1) learning theoretical review and followed by involving students on business activities, (2) learning theoretical review and followed with business practices, and (3) learning entrepreneurship with theoretical review in classical systems.

The result of this study is similar with the opinion that strengthening entrepreneurship requires experience, and to gain the experience, one must involve in business activity. O'Connor (2012) explains this opinion as a learning activity through entrepreneurship activities. It means learners are taught entrepreneurship by involving them in business activities; so they get experience how to run business activities and become entrepreneurs.

The results of this study are also in line with Kuratko's (2005) and Jones \& Iradale (2010) views which state that effective entrepreneurship learning is not enough to be applied only through pedagogic activities by emphasizing theoretical studies, and only full of entrepreneurship discussion. Learners should be encouraged to practice the entrepreneurial theory that they have already received, and involve them more in business activities. Thus the students will also be able to construct knowledge about entrepreneurship through grounded theory activities. Jones \& Iradale (2010) in the study called entrepreneurship learning by involving learners in business activities as an enterprise education term.

This study proves that the learning model of enterprise education is effective to improve students' entrepreneurship competence and students 'entrepreneurship intention. The findings of this study confirm the views of previous researchers, such as: Lackeus (2013), Mwasalwiba (2010), and Fayolle \& Gailly (2008). These earlier researchers revealed that efforts to improve entrepreneurship competence and entrepreneurship intention of students should be done with more opportunities for them to involve directly in business activities and become entrepreneurs.

\section{Conclusion and Suggestion}

The approach of effective entrepreneurship learning that can increase entrepreneurship competence and entrepreneurship interests of students are (1) Learning entrepreneurship theoretically and followed by involving students directly on business activities, (2) Learning entrepreneurship theoretically and followed with business practices. Through these two learning approaches, the aspect of competences significantly increase for the aspect of Opportunity skills, (S6) resource skills, (S7) interpersonal skills, (S8) learning skills, and (S9) Strategic skills. While the students entrepreneurship attitudes significantly increase for: (A10) entrepreneurial passion, (A11) confidence and self efficacy, and (A14) innovativeness. While Students entrepreneurship intention significantly increase for the aspect of: (I7) encourage to entrepreneurship, (I8) immediately manifests after graduation, (I3) entrepreneurship effort, (I9) set the entrepreneurial profession as the first choice, (I2) interested in becoming entrepreneur, (I6) hope for entrepreneurship, and (I5) desire for entrepreneurship. Based on the conclusions of the study, the researchers recommend to schools to strengthen entrepreneurship learning that engages more learners in business practices and involves them in business activities. To that end, the school can optimize the business center function and strengthen cooperation with business institutions to support entrepreneurship learning activities.

\section{References}

Ajzen, I. 1991. Theory of planned behavior. Organizational Behavior and Human Decision Processes, 50, 179211.

Bird, B., \& Jelinek, M. 1988. The operation of entrepreneurial intentions. Entrepreneurship: Theory \& Practice, $13,(2), 21-30$.

Coduras, A; Urbano, D., Rojas, A; \& Martinez, S. 2008. The relationship between university support to entrepreneurship with entrepreneurial activity in Spain: A GEM data based analysis. International Advanced Economic Research. 14 (4) 395-406

Davidson, P. 1995. Culture, Structure, and Regional Levels of Entrepreneurship. Entrepreneurship and Regional Development. 7. Pp. 41-62

Drucker, P.F.1985. Innovation and Entrepreneurship $\left(1^{\text {st }}\right.$ Edition $)$. New York: Harper and Row

Fayolle, A. \& Gailly, B. 2008. From craft to science - teaching model and learning processes in entrepreneurship education. Journal of European Industrial Training, 32 (7) pp.569-593.

Fisher, S.; Graham, M.; \& Compeau, M. 2008. Starting from Scratch: Understanding the learning outcomes of undergraduate entrepreneurship education. Journal of European Industrial Training, 32 (7) pp.569-593 
Gerry. C, Susana. C. \& Nogueira. F. 2008. Tracking Student Entrepreneurial Potential: Personal Attributes and the Propensity for Business Start-Ups after Graduation in a Portuguese University. International Research Journal Problems and Perspectives in Management, 6(4): 45-53.

Goel, Abhishek; Vohra, Neharika; Zhang, Liyan; Arora, Bhupinder. 2007. Attitudes of The Youth Towards Entrepreneurs and Entrepreneurship: A Cross-Cultural Comparison of India and China. Journal of Asia Entrepreneurship and Sustainability. Vol. III pp. 29-62

Gorman, G., Hanlon, D. \& King, W. 1997. Some Research Perspectives on Entrepreneurship Education, Enterprise Education and Education for Small Business Management: A Ten Year Literature Review. International Small Business Journal, 15(3): 56-77.

Gurbuz, G. \& Aykol, S. 2008, Entrepreneurial Intentions of Young Educated Public in Turkey. Journal of Global Strategic Management, 4(1): 47-56.

Haryono, Kir. 1995. Pendidikan Kejuruan dan Filosofinya Sebagai Sistem Pendidikan Bagi Semua. Yogjakarta: Cakrawala Pendidikan Dies Special Edition

Heinonen, J. \& Hytti, U. 2010. Back to basic: The role of teaching in developing the entrepreneurial university. The International Journal of Entrepreneurship and Innovation, 11 (4) pp. 283-292

Izedomi, P.F. \& Okafor, C. 2010. The effect of entrepreneurship education on students' entrepreneurial intention. Global Journal of Management and Business Research. 10 (6) 49-60.

Johannisson, B.; 1991. University training for entrepreneurship: Swedish approaches. Entrepreneurship\& Regional Development, 3 (1) pp. 67-82

Jones, B \& Iradale, N. 2010. Enterprise education as pedagogy. Education + Training, 52 (1) pp.7-19

Kraiger, K.; Ford, J.K.; \& Salas, E. 1993. Application of cognitive, skills based, and affective theories of learning outcomes to new methods of training evaluation. Journal of Applied Psychology, 78 (2) pp. 331-328

Krueger, N.F. Jr., Reilly, M.D., \& Carsrud, A.L. 2000. Competing models of entrepreneurial intentions. Journal of Business Venturing, 15, 411-432.

Kuratko,D.F.2005. The emergence of entrepreneurship education: Development, trends, and challenges. Entrepreneurship Theory and Practice. 29 (5) pp.577-597

Kumar, Suresh; Vifenda, Agata Trevelin; Brigitta, Maria; \& Valerie. 2013. Students' willingness to become a entrepreneur: A survey of non-business students of President University. IOSR Journal of Business and Management (IOSR-JBM), 15(2) pp 94-102.

Kyro, P. 2008. Atheoritical framework for teaching and learning entrepreneurship. International Journal of Business and Globalization, 2 (1) pp. 39-55

Lackeus, Martin. 2013. Developing Entrepreneurial Competencies: An action approach and classification in entrepreneurial education. Thesis for the degree of licentiate of engineering. Gothenburg, Sweden: Division of Management of Organization Renewal and Entrepreneurship, Department of Technology Management and Economics, Chalmers University of Technology

Lange, J.E.; Marram, E.; Jawahar, A.S.; Yong, W; \& Bygrave, W. 2011. Does an entrepreneurship education have lasting value? A study of careers of 4.000 alumni. Frontiers of Entrepreneurship Research. 31 (6) pp210224

Lynes, Jennifer; Wismer, Susan; dan Andrachuk, Mark (2011). The Role of Education in Entrepreneurship: Two Canadian Stories. Advancing Women in Leadership. Vol. 31 pp. 14-22.

Markman, G.D.; Baron, R.A. \& Balkin, D.B. 2005. Are perseverance and self-efficacy costless? Assessing entrepreneurs' regretful thinking. Journal of Organizational Behavior, 26 (1) pp. 1-19

Matthews, C.H. dan Moser, S.B. 1995. Family Background and Gender: Implication for Interest in Small Firm Ownership. Entrepreneurship and Regional Development. No. 7 pp. 365-377

Mwasalwiba, E.S. 2010. Entrepreneurship education: A review of its objectives, teaching methods, and impact indicators. Education + Training, 52 (1) pp. 20-47

Menzies, T.V. \& Paradi, J.C.2002. Encouraging technology-based ventures: entrepreneurship education and engineering graduates. New England Journal of Entrepreneurship, 5 (2) 57-64

Ministry of Economic Affairs (2000). Entrepreneurship in the Netherlands: opportunities and threats to nascent entrepreneurship. Retrieved August 3, 2004, from the World Wide Web:

http://www.exist.de/kooperation/dateien/9_nl11r29.pdf 
Mitchell, Ronald K.; Busenitz, LowellW.; Bird, Barbara; Gaglio, Connie Marie; McMullen, Jeffery S.; Morse, Eric A.; Smith, J. Brock. January 2007. The central question in entrepreneurial cognition research 2007. Entrepreneurship Theory and Practice, pp. 1-27

Moore, D.R.; Cheng, M.I.; \& Dainty, A.R. 2002. Competence, competency, and competencies: Performance assessment in organization. Work Study, 51 (6) pp. 314-319

Mulyani, Endang.2010. Pengembangan Pendidikan Kewirausahaan. (Developing Entrepreneurship Education) Jakarta: Pusat Kurikulum (Curriculum Center), Badang Penelitian dan Pengembangan (Agency for Research and Development), Kementerian Pendidikan Nasional. (Ministry of National Edecation)

Murnieks, C.Y. 2007. Who am I? The quest for an entrepreneurial identity and an investigation of its relationship to entrepreneurial passion and goal setting. Doctoral-Thesis, University of Colorado

Nishanta, B. 2008. Influence of Personality Traits and Socio-demographic Background of Undergraduate Students on Motivation for Entrepreneurial Career: The Case of Srilanka. Paper was presented at the Euro-Asia Management Studies Association (EAMSA) Conference, Japan.

Nuh, Muhammad.2010. Desain Induk Pengembangan Pendidikan Karakter Kemenerian Pendidikan Nasional. (Main Design for Developing Character Education Ministry of National Edecation) Jakarta: Kementerian Pendidikan Nasional (Ministry of National Edecation)

O'Connor, A. 2013. A conceptual frame work for entrepreneurship education policy: Meeting government and economic purposes. Journal of Business Venturing, 24 (1) pp. 1-22

Prianto, Agus; Firman; Asmuni; dan Maisaroh, Siti. 2017. The effect of academic performance and the involvement in the internship program toward life skills and work readiness of university graduates in East Java Indonesia. International Journal of Business and Management Invention. Volume 6 Issue 8. August 2017. Pp. 41-55

Prianto, Agus. 2017. Various variables to trigger entrepreneurial intention for young entrepreneurs in East Java Indonesia. International Journal of Business and Management Invention. Volume 6 Issue 4. April 2017. Pp. 32-44

Prianto, Agus. 2015. Problem in an entrepreneurship culture: Indonesia's challenge in facing Asean Economic Community. The International Journal of Humanities \& Social Studies. Vol. 3 Issue 12. pp. 215-223

Rasheed, H.S. 2000. Developing Entrepreneurial Potential in Youth: The Effects of Entrepreneurial Education and Venture Creation, http://USASEB2001proceedings063

Stewart, W.H., Watson, W.E., Carland, J.C. \& Carland, J.W. 1998. A Proclivity for Entrepreneurship: A Comparison of Entrepreneurs, Small Business Owners, and Corporate Managers". Journal of Business Venturing, 14(2): 189-214.

Usman, Husaini dan Raharjo, Nuryadin Eko. Oktober 2012. Model Pendidikan Karakter Kewirausahaan di Sekolah Menengah Kejuruan. (Entrepreneurship Character Education Model at Vacational High School) Jurnal Pendidikan Teknologi dan Kejuruan (Journal of Technology and Vacation). Vol.21 No. 2 pp. 140147

Weaver, M.; Dickson, P.; \& Soloman, G.2006. Chapter 5: Entrepreneurship and Education: What is known and not known about the links between education and entrepreneurial activity. Small Business Economy. United States Small Business Administration, Office and Advocacy, 113-156. 